\title{
Pemahaman Guru Bahasa Indonesia SMA, SMK Dan MA Di Kota Mataram Terhadap Pembelajaran Bahasa Indonesia Berbasis Teks
}

\author{
${ }^{1}$ Nurfidah, ${ }^{2}$ Mahsun, ${ }^{3}$ Burhanuddin \\ ${ }^{123}$ Magister Pendidikan Bahasa Indonesia, Universitas Mataram \\ Nurfidah02@gmail.com
}

\begin{abstract}
Abstrak. Penelitian ini bertujuan untuk memperoleh informasi mengenai pemahaman guru bahasa indonesia SMA, SMK, MA di Kota Mataram terhadap pembelajaran bahasa Indonesia berbasis teks. Jenis penelitian ini merupakan penelitian deskriptif dengan menggunakan pendekatan kualitatif dan kuantitatif. Sasaran dalam penelitian ini adalah guru bahasa Indonesia SMA, SMK, dan MA di Kota Mataram. Metode yang digunakan dalam proses pengumpulan data dalam penilitian ini yaitu metode simak dan metode cakap. Sedangkan metode yang digunakan dalam analisis data adalah metode padan intralingual teknik HBB, HBS, dan HBSP. Berdasarkan hasil analisis diperoleh hasil bahwa pemahaman guru bahasa Indonesia SMA, SMK, MA di Kota Mataram terhadap pembelajaran bahasa Indonesia berbasis teks berkategori Pemahaman guru bahasa Indonesia SMA, SMK, dan MA di Kota Mataram terhadap pembelajaran bahasa Indonesia berbasis teks mampu memahami jenis-jenis teks berdasarkan genrenya, karena semua responden mampu mendeskripsikan pemahamannya dalam teks itu sendiri. Dari sudut pandang pemahaman guru bahasa Indonesia SMA, SMK, dan MA di Kota Mataram terhadap pembelajaran bahasa Indonesia berbasis teks mampu memahami struktur teks berdasarkan genrenya, karena semua responden mampu mendeskripsikan pemahamannya dalam teks berdasarkan genrenya. Pemahaman guru bahasa Indonesia SMA, SMK, dan MA di Kota Mataram terhadap pembelajaran bahasa Indonesia berbasis teks kurang mampu memahami penggunaan piranti kebahasaan dalam teks, karena sebagian besar responden kurang mampu mendeskripsikan pemahamannya dalam teks berdasarkan genrenya. Dan terakhir, pemahaman guru bahasa Indonesia SMA, SMK, dan MA di Kota Mataram terhadap pembelajaran bahasa Indonesia berbasis teks di Kota Mataram mampu memahami tujuan sosial dalam teks, karena semua responden mampu mendeskripsikan pemahamannya dalam teks berdasarkan genrenya.
\end{abstract}

Kata Kunci: Pemahaman Guru, Pembelajaran Bahasa Indonesia, Teks.

\section{PENDAHULUAN}

Terdapat perubahan mendasar dalam Kurikulum 2013, khusus bidang mata pelajaran bahasa Indonesia, telah mengubah paradigma pembelajaran dari yang bersifat struktural ke paradigma memandang bahasa sebagai sebuah sistem yang fungsional (sistemik fungsional). Perubahan dimaksud terjadi pada paradigma penetapan satuan kebahasaan yang menjadi basis materi pembelajaran. Perubahan pada materi tersebut, membawa dampak pada perubahan metode pembelajaran. Adapun satuan bahasa yang menjadi basis pembelajaran adalah teks. Teks adalah satuan bahasa yang sedang menjalankan fungsi (Halliday, 1992). Sebagai satuan bahasa yang sedang menjalankan fungsinya, teks dapat dikatakan sebagai unit bahasa yang memiliki gagasan/pikiran yang lengkap. Oleh karena itu, pembelajaran bahasa berbasis teks, selain ditujukan agar siswa dapat menggunakan bahasa sesuai konteksnya juga dapat menjadi sarana pengembangan kemampuan berpikir.

Selanjutnya, perubahan kurikulum dengan paradigma pembelajaran yang turut berubah, tentu saja membawa konsekuensi berupa tuntutan penyesuaian yang fundamental dari para guru. Penyesuaian dimaksud tidak hanya menyangkut tuntutan agar guru harus benar-benar memahami substansi satuan bahasa yang akan diajarkan, yaitu teks (standar isi), tetapi juga tuntutan agar guru memahami standar kompetensi lulusan yang hendak dicapai dengan pemberian materi pembelajaran, memahami cara-cara materi itu dibelajarkan (standar proses pembelajaran), dan memahami 
bagaimana capaian pembelajaraan itu dievaluasi (standar proses penilaian). Untuk mengetahui sejauh mana perubahan itu dapat disiasati para guru, melalui tujuan akhir pembelajaran bahasa Indonesia berbasis teks di atas dapat dicapai, maka perlu dilakukan kajian penerapan kurikulum Bahasa Indonesia berbasis teks.

Pembelajaran bahasa Indonesia berbasis teks menuntut pendidik siap menjadi fasilitator pembelajaran. Pembelajaran harus sebanyak mungkin melibatkan siswa agar mampu bereksplorasi untuk membentuk kompetensi dengan menggali berbagai potensi yang dimiliki. Berpijak pada hasil observasi awal, tampaknya kemampuan guru memahami teks dapat dikatakan masih kurang. Permasalahan yang dihadapi oleh guru berupa kesulitan dalam membedakan teks berdasarkan genrenya, struktur teks, dan penggunaan piranti kebahasaan dalam berbagai teks bahkan tujuan sosial dari teks itu sendiri, karena setiap pembelajaran yang diajarkan harus dikaitkan dengan kehidupan sehari-hari. Oleh sebab itu, guru-guru mata pelajaran masih kurang maksimal dalam pelaksanaan pembelajaran berbasis teks, sehingga pemahaman guru terkait pembelajaran bahasa Indonesia berbasis teks berkategori rendah dilihat dari hasil pencapaian siswa itu sendiri.

Terkait dengan penelitian ini, pemahaman guru terhadap pembelajaran berbasis teks belum dilakukan oleh para peneliti dan belum ada hasil survei terdahulu khususnya di Kota Mataram. Oleh karena itu, penelitian ini dilakukan untuk mengukur pemahaman guru dalam memahami standar isi khususnya dalam memahami materi pembelajaran bahasa Indonesia berbasis teks. Hal ini penting dilakukan karena terlaksananya penerapan kurikulum 2013 khususnya pembelajaran bahasa Indonesia salah satunya ditentukan oleh pemahaman guru terhadap pembelajaran berbasis teks. Pembelajaran berbasis teks masih banyak guru yang mengalami kebingungan, kesulitan beradaptasi, dan bertahan menerapkan gaya mengajar serta metode konvensional akibat adanya peralihan dari kurikulum sebelumnya. Fenomena ini tentu saja mempengaruhi capaian/hasil belajar siswa. Berpijak pada hasil observasi awal, tampaknya pemahaman guru memahami teks dapat dikatakan masih kurang.
Kendala yang dihadapi guru pada umumnya berupa kesulitan dalam membedakan teks berdasarkan genrenya, akibat kurang pemahaman guru bahasa Indonesia terhadap pembelajaran bahasa Indonesia berbasis teks.

Berdasarkan masalah di atas penelitian ini bertujuan untuk mendeskripsikan pemahaman guru bahasa Indonesia terhadap pembelajaran berbasis teks di SMAN 1 Mataram, SMKN 4 Mataram, MAN 1 Mataram, SMAK Kesuma Mataram, SMA Nasional Mataram, dan MA Hidayatullah Mataram. Melalui Pendeskripsian pemahaman guru bahasa Indonesia dalam menerapkan kurikulum 2013 pada tahun 2014 kurang lebih lima tahun berjalan. Sehingga, ada upaya untuk meningkatkan kualitas pendidikan terutama guru yang akan membimbing siswa yang bisa menyusaikan diri dengan berbagai masalah.

Untuk itu, penelitian ini difokuskan pada topik yang berhubungan dengan standar isi: Pemahaman guru bahasa Indonesia terhadap pembelajaran bahasa Indonesia berbasis teks terdapat empat masalah pokok dalam penelitian ini yaitu (1) pemahaman guru bahasa Indonesia terhadap jenis-jenis teks berdasarkan genrenya, (2) pemahaman guru terhadap struktur teks sesuai dengan genrenya, (3) pemahaman guru atas penggunaan piranti kebahasaan dalam berbagai jenis teks sesuai dengan genrenya, (4) pemahaman guru terhadap tujuan sosial masingmasing teks sesuai dengan genrenya.

\section{KAJIAN PUSTAKA}

Berdasarkan masalah di atas penelitian ini bertujuan untuk mendeskripsikan pemahaman guru bahasa Indonesia terhadap pembelajaran berbasis teks di Kota Mataram. Melalui Pendeskripsian pemahaman guru bahasa Indonesia yang selama menerapkan kurikulum 2013 pada tahun 2014 kurang lebih lima tahun berjalan. Sehingga, ada upaya untuk meningkatkan kualitas pendidikan terutama guru yang akan membimbing siswa yang bisa menyusaikan diri dengan berbagai masalah.

Hasil-hasil penelitian yang telah dilakukan sebelumnya, yakni: Pertama, Pembelajaran bahasa Indonesia berdasarkan pendekatan saintifik (problem based learning) sesuai kurikulum 2013 di kelas VII SMP Negeri 2 Amlapura, Bintari, (2014). Kedua, pembelajaran bahasa indonesia berbasis teks di 
kelas X SMA Negeri 1 Singaraja, Suryani, (2014). Ketiga, mengenai implementasi pembelajaran bahasa Indonesia berbasis teks di SMP Negeri Kota Bukittinggi, Afrila, dkk. (2018). Keempat, pemahaman Guru Bahasa Indonesia SMP dan SMA dalam mengembangkan butir-butir pembelajaran kebahasaan dengan pendekatan komunikatif berbasis teks, Harahap, (2018). Kelima, implementasi pembelajaran bahasa indonesia berbasis teks di SMP Negeri Kabupaten Padang Pariaman, Rahman, dkk. (2018).

Oleh karena itu, penelitian ini dilakukan untuk mengukur pemahaman guru dalam memahami standar isi khususnya dalam memahami materi pembelajaran bahasa Indonesia berbasis teks. Tinjauan pustaka memiliki relevan dengan penelitian pemahaman guru bahasa Indonesia terhadap pembelajaran bahasa Indonesia berbasis teks. Relevansi tersebut dapat dijadikan sebagai bahan perbandingan dan pertimbangan penelitian ini yang secara langsung terkait dengan kerangka teori, metode, dan hasil penelitian terdahulu.

\section{KonsepTeoritis}

\section{Konsep Pemahaman Guru}

Pemahaman berasal dari kata paham yang memiliki arti beragam seperti perhatian, pendapat, pandai, mengerti benar sesuatu hal dan pemahaman merupakan proses, perbuatan, atau cara memahami (Tim Prima Pena, tt, 481). Pemahaman seseorang terhadap sesuatu objek harus disaarkan pada ilmu yang dimilik, karena dengan ilmu seseorang dapat membaca, memikirkan, menganalisis sekaligus memahami apa yang menjadi kajiannya (Irwan, 2011:52). Menurut Daryanto (2008:106) kemampuan pemahaman dapat dijabarkan menjadi beberapa kategori diantaranya: (a) Menerjemahkan (Translation), (b) Menafsirkan (Interpretion), (c) Mengekstrapolasikan (ekstrapolation).

\section{Pembelajaran Bahasa Indonesia Berbasis Teks}

Pembelajaran bahasa Indonesia untuk jenjang menengah atas disusun dengan berbasis teks, baik lisan maupun tulis, dengan menempatkan bahasa Indonesia sebagai wahana untuk mengekspresikan perasaan dan pemikiran. Siswa diharapkan mampu menggunakan dan memproduksi berbagai teks sesuai dengan tujuan dan fungsi sosialnya dalam kurikulum
2013 (Kemendikbud, 2017). Untuk itu, dalam pembelajaran bahasa Indonesia dengan menggunakan buku bahasa Indonesia, guru hendaknya menempuh empat tahap pembelajaran, yaitu (1) penentuan konteks teks dan membangun pengetahuan tentang teks yang akan dipelajari, (2) pemodelan dan dekonstruksi, (3) konstruksi siswa dibantu guru dalam berbagai latihan dan tugas hingga menyusun teks sasaran (join construction), (4) tugas dan latihan teks sasaran secara mandiri yang minim bantuan guru (independent construction). Prosedur ini diwabahi dalam buku teks yang memiliki empat bagian, yaitu (1) membangun konteks; (2) pemodelan dan dekontruksi; (3) prakonstruksi; dan (4) konstruksi. Kegiatan dalam setiap prosedur diharapkan bervariasi dan sesuai dengan jenis teks yang dipelajari (Kemendikbud, 2017).

\section{Teks Dalam Kurikulum 2013}

Terdapat perubahan mendasar dalam kurikulum 2013, khususnya bidang pembelajaran bahasa Indonesia. perubahan dimaksud terjadi pada paradigm penetapan satuan kebahasaan yang menjadi basis materi pembelajaran. perubahan pada materi tersebut, membawa dampak pada perubahan metode pembelajaran. Adapun satuan bahasa yang menjadi basis pembelajarannya adalah teks. Jadi, pembelajaran bahasa dilakukan dengan mempertimbangkan konteks situasi pemakaian bahasa itu sendiri.

Mahsun, (2018:99) menyatakan bahwa teks dijadikan basis pembelajaran kurikulum 2013. Pertama, melalui teks kemampuan berpikir siswa dapat dikembangkan; kedua, materi pembelajaran berupa teks lebih relevan dngan karakteristik kurikulum 2013 yang menetapkan capaian kompetensi siswa yang mencakupi ketiga ranah pendidikan: pengetahuan, keterampilan, dan sikap.

Kurikulum bahasa Indonesia 2013, dilaksanakan dengan menerapkan prinsip: (1) bahasa hendaknya dipandang sebagai teks, bukan semata-mata kumpulan kata-kata atau kaidah-kaidah kebahasaan, (2) penggunaan bahasa merupakan proses pemilihan bentukbentuk kebahasaan untuk mengungkapkan makna, (3) bahasa bersifat fungsional, yaitu penggunaan bahasa yang tidak pernah dapat dilepaskan dari konteks karena dalam bentuk 
bahasa yang digunakan itu tercermin ide, sikap, nilai, dan ideology penggunanya, dan (4) bahasa merupakan sarana pembentukan kemampuan berpikir manusia.

Harsiati dkk. (2016), mengemukakan tujuan kurikulum bahasa berbasis teks siswa diharapkan dapat memproduksi dan menggunakan teks sesuai dengan tujuan dan fungsi sosialnya. Bahasa Indonesia diajarkan bukan sekedar sebagai pengetahuan bahasa, melainkan terintegrasi dengan teks yang berfungsi untuk menjadi sumber aktualisasi diri kegiatan berbahasa pada konteks sosial-budaya akademis. Teks dipandang sebagai satuan bahasa yang bermakna secara kontekstual. Oleh karena itu, kurikulum bahasa Indonesia 2013, dikatakan juga pembelajaran bahasa berbasis teks.

\section{Landasan Teori \\ Teks}

Halliday dan Ruqaiyah 1992 menyebutkan bahwa teks merupakan jalan menuju pemahaman tentang bahasa. Itu sebabnya, teks menurutnya merupakan bahasa yang berfungsi atau bahasa yang sedang melaksanakan tugas tertentu dalam konteks situasi disebut teks, dipaparkan juga oleh Mahsun (2018:3) bahwa antara teks dengan konteks sosial dan konteks budaya memiliki relasi pendasaran. Konteks budaya akan mempengaruhi konteks sosial. Akibatnya refleksi konteks sosial yang berwujud teks pun akan ditentukan oleh kedua konteks situasi (sosial dan budaya) tersebut.
Lebih
lanjut
Mahsun
(2018:1)

menyatakan batasan ini mengandung pengertian bahwa setiap pemakaian bahasa selalu memiliki tujuan. Tujuan yang dimaksudkan disini tentu tujuan social, karena bahasa tidak lain merupakan sarana untuk melaksanakan proses sosial.

Mahsun (2018:12-13) menjelaskan bahwa secara umum, teks dapat diklasifikasikan atas teks tunggal/genre mikro dan teks majemuk/genre makro. Istilah tunggal dan majemuk yang disematkan pada konsep teks tunggal dan teks majemuk beranalogi pada konsep tunggal dan majemuk dalam kalimat tunggal dan kalimat majemuk.

\section{Jenis-Jenis Teks Berdasarkan Genrenya}

Berdasarkan sudut pandang penceritaannya, maka genre atau ragam teks tersebut dapat dipilah ke dalam dua kelompok besar, yaitu teks-teks yang termasuk dalam genre sastra dan genre nonsastra. sementara itu, teks-teks dalam kelompok genre sastra dikategorikan dalam genre cerita. Sedangkan teks-teks genre nonsastra dikelompokkan ke dalam genre faktual dan genre tanggapan, baik genre cerita maupun genre faktual dan genre tanggapan masing-masing dikelompokkan ke dalam dua kelompok subgenre, yaitu: (1) Subgenre naratif dan nonnaratif untuk kategori genre cerita, (2) Subgenre laporan dan prosedural untuk kategori genre faktual, (3) Subgenre transaksional dan ekspositori untuk kategori genre tanggapan. (Sumber, Mahsun:2018:16).

\section{Struktur Teks}

Struktur teks berkenaan dengan bagianbagian yang berfungsi sebagai unsure pembentuk teks. Pada umumnya teks terdiri atas tiga bagian, yaitu bagian awal, bagian tubuh, dan bagian akhir. Struktur dapat menjadi salah satu cirri setiap jenis teks. Jenis teks yang satu dengan jenis teks yang lain memiliki perbedaan struktur.

\section{Piranti Kebahasaan dalam Teks}

Piranti-piranti kebahasaan dalam teks berkaitan dengan tiga hal yaitu penggunaan piranti penghubung intra kalimat, penggunaan piranti penghubung antar kalimat, dan penggunaan piranti penghubung antar paragraf.

Penghubung intra kalimat adalah ungkapan/kata dalam sebuah kalimat yang berfungsi menghubungkan unsur-unsur kalimat (badanbahasa.Kemendikbud.go.id). Ada dua penggunaan piranti penghubung intra kalimat yaitu penggunaan konjungsi kesetaraan dan penggunaan konjungsi kebertingkatan: (1) Konjungsi kesetaraan merupakan penggabungan dua klausa atau lebih yang masing-masing mempunyai kedudukan setara dalam struktur kalimat, (2) Konjungsi kebertingkatan merupakan menggabungkan dua klausa atau lebih secara bertingkat (Miftahul K. dan Sakura R., 2014:182-186).

Penggunaan piranti penghubung antar kalimat salah satu kata sambung yang menghubungkan antara kalimat satu dengan kalimat yang lainnya. Penggunaan piranti 
penghubung antar kalimat yang mencakupi: (1) repetisi/pengulangan bentuk, (2) pengulangan makna disajikan dalam wujud pengulangan bentuk, (3) pengulangan dalam wujud anaphora, (4) pengulangan dalam wujud sinonim, (5) pengulangan dalam wujud antonim, pengulangan dalam wujud hiponim, dan (7) penggunaan konjungsi antar kalimat (Mahsun, 2017:381-382).

Penggunaan piranti penghubung antar paragraf merupakan kata penghubung/konjungsi yang menghubungkan dua paragraf yang memiliki keterkaitan makna. Penggunaan piranti penghubung antar paragraf yang mencakupi: repetisi/pengulangan bentuk, pengulangan makna disajikan dalam wujud pengulangan bentuk, pengulangan dalam wujud anaphora, pengulangan dalam wujud sinonim, pengulangan dalam wujud antonim, pengulangan dalam wujud hiponim dan penggunaan konjungsi antar paragraf (Mahsun, 2017:381-382).

\section{METODE PENELITIAN}

Penelitian ini mendeskripsikan tentang bagaimana pemahaman guru bahasa Indonesia SMA, SMK, dan MA di Kota Mataram terhadap pembelajaran bahasa Indonesia berbasis teks. Oleh karena itu, penelitian ini menggunakan metode penelitian kualitatif. Penelitian ini dilakukan dengan mengamati subjek dan objek penelitian berdasarkan fakta-fakta yang ada. Fakta yang ditemukan dideskripsikan secara mendalam. Dalam penelitian ini, peneliti merupakan pengumpul data utama artinya penelitian tidak dapat diwakilkan. peneliti berperan serta dalam kegiatan yang dilakukan subjek penelitian sehingga peneliti mendapatkan informasi yang akurat.

Penelitian ini dilaksanakan di SMAN 1 Mataram, SMKN 4 Mataram, MAN 1 Mataram, SMAK Kesuma Mataram, SMK Muhammadiyah Mataram, dan MA Hidayatullah Mataram. Selanjutnya, masingmasing sekolah sampel ditetapkan jumlah responden Guru bahasa Indonesia yang dipilih sesuai dengan asumsi guru yang sudah mendapatkan pelatihan kurikulum 2013 sehingga responden tidak bisa dipilih secara acak, dengan asumsi semua Guru bahasa Indonesia tersebut memiliki peluang yang sama untuk menjadi responden. Dengan demikian responden penelitian ini berjumlah 12 orang guru dan setiap sekolah negeri hanya 3 responden dan berhubung di sekolah swasta kekurangan guru bahasa Indonesia, maka 1 responden di setiap sekolah swasta.

Metode penggumpulan data yang digunakan dalam penelitian ini yaitu metode cakap. Metode cakap yang digunakan dalam penelitian ini dilanjutkan dengan teknik dasar berupa teknik pancing dengan teknik lanjutan berupa teknik cakap semuka dan teknik cakap tansemuka.

Data yang sudah tersedia selanjutnya dianalisis. Data akan dianalisis secara kualitatif dan kuantitatif. Untuk menganalisis data secara kualitatif digunakan metode padan intralingual teknik HBB, HBS, dan HBSP (Mahsun 2017).

Setelah menganalisis data secara kualitatif, langkah selanjutnya adalah menganalisis data secara kuantitatif dengan menggunakan metode padan ekstra-lingual teknik HBS, HBB, dan HBSP.

Dengan menggunakan rentang nilai nol sampai dengan sepuluh (0-10), maka bobot untuk masing-masing variabel di atas diperlihatkan berikut ini.

Tabel 1. Skor Variabel Pemahaman Guru Bahasa Indonesia Terhadap Pembelajaran Bahasa Indonesia Berbasis Teks

\begin{tabular}{|c|l|c|}
\hline No & \multicolumn{1}{|c|}{ Variabel } & Skor \\
\hline 1. & $\begin{array}{l}\text { Pemahaman guru bahasa indonesia terhadap jenis- } \\
\text { jenis teks berdasarkan genrenya }\end{array}$ & 1 \\
\hline 2. & $\begin{array}{l}\text { Pemahamn Guru Terhadap Struktur Teks sesuai } \\
\text { dengan genrenya }\end{array}$ & 3 \\
\hline 3. & $\begin{array}{l}\text { Pemahaman Guru atas Penggunaan Piranti } \\
\text { Kebahasaan Dalam berbagai jenis Teks sesuai dengan } \\
\text { genrenya }\end{array}$ & 4 \\
\hline 4. & $\begin{array}{l}\text { Pemahaman guru terhadap tujuan sosial masing- } \\
\text { masing teks sesuai dengan genrenya }\end{array}$ & 2 \\
\hline \multicolumn{1}{|c|}{ Total Skor } & 10 \\
\hline
\end{tabular}

Dengan ditetapkannya bobot masingmasing variabel, analisis kuantitatif perlu menetapkan kategori penjenjangan pemahaman guru. Kategori penjenjangan ini sejatinya dapat memperkaya dan memperkuat pemerian/deskripsi data kualitatif serta sebagai dasar pijakan penetapan tingkat capaian pemahaman guru. Berikut rentang skor untuk memaknai penjenjangan kemampuan tersebut. 
Tabel 2. Rentang Skor Penjenjangan Kategori Pemahaman Guru Terhadap Pembelajaran Berbasis Teks

\begin{tabular}{|c|c|c|}
\hline No & Variabel & Skor \\
\hline 1. & Sangat Baik & 91 ke atas \\
\hline 2. & Baik & $79-90$ \\
\hline 3. & Cukup & $67-78$ \\
\hline 4. & Kurang & 66 ke bawah \\
\hline
\end{tabular}

(periksa Mahsun, 2017)

Setelah peneliti menetapkan kategori penjenjangan pemahaman guru terhadap pembelajaran berbasis teks, tahapan analisis selanjutnya adalah (a) menghitung skor capaian setiap sampel penelitian berupa variable nonkebahasaan sebagaimana telah dipaparkan sebelumnya yakni untuk mengetahui tingkat pemahaman berdasarkan kategori asing-masing sampel, (b) menghitung skor keseluruhan dengan cara menggabungkan skor keseluruhan sampel lalu dibagi jumlah skor akhir. Langkah ini dimaksudkan untuk membuat konklusi secara umum tentang kondisi pemahaman guru, dalam hal ini analisis pemahaman guru terhadap pembelajaran bahasa Indonesia berbasis teks, (c) Membuat deskripsi kualitatif setiap jenjang capaian pemahaman berdasarkan hasil pemetaan kualitatif, untuk memberi pemaknaan atas jenjang pemahaman yang dicapai masingmasing sekolah sampel penelitian.

\section{HASIL DAN PEMBAHASAN \\ Hasil}

Pemahaman guru bahasa Indonesia terhadap jenis teks berdasarkan genrenya

Sesuai tujuan yang ingin dicapai, pemahaman guru bahasa Indonesia terhadap jenis teks yang akan diidentifikasikan mencakup 3 jenis yaitu cerpen, eksposisi, dan prosedur.

Berdasarkan hasil pengumpulan data bahwa pemahaman guru bahasa Indonesia terhadap jenis teks cerpen, eksposisi, dan prosedur maka, diperoleh data sebagai berikut.

Tabel 3 Pemahaman Guru Bahasa Indonesia terhadap Jenis Teks Cerpen dalam Pembelajaran Bahasa Indonesia Berbasis Teks

\begin{tabular}{|l|l|c|c|}
\hline No. & \multicolumn{1}{|c|}{ Nama Sekolah } & $\begin{array}{c}\text { Jawaban } \\
\text { responden }\end{array}$ & Skor \\
\hline 1. & MAN 1 Mataram & Benar & 1 \\
\hline 2. & MA Hidayatullah Mataram & Benar & 1 \\
\hline 3. & SMAN 1 Mataram & Benar & 1 \\
\hline 4. & SMAK Kesuma Mataram & Benar & 1 \\
\hline 5. & SMKN 4 Mataram & Benar & 1 \\
\hline 6. & SMK Muhammadiyah Mataram & Benar & 1 \\
\hline
\end{tabular}

Data di atas merupakan hasil rekapitulasi dari responden yang dimana setiap sekolah diambil satu responden untuk menjawab tentang jenis teks yang berupa jenis teks cerpen dan jawaban-jawaban itu tertera pada tabel 1. Jika dicermati pada tabel di atas dari enam responden menunjukkan bahwa responden menjawab dengan benar sehingga semua di beri skor 1 .

Tabel 4 Pemahaman Guru Bahasa Indonesia terhadap Jenis Teks Eksposisi dalam Pembelajaran Bahasa Indonesia Berbasis Teks

\begin{tabular}{|l|l|c|c|}
\hline $\begin{array}{l}\text { No } \\
.\end{array}$ & \multicolumn{1}{|c|}{ Nama Sekolah } & $\begin{array}{c}\text { Jawaban } \\
\text { responden }\end{array}$ & Skor \\
\hline 1. & MAN 1 Mataram & Benar & 1 \\
\hline 2. & MA Hidayatullah Mataram & Benar & 1 \\
\hline 3. & SMAN 1 Mataram & Benar & 1 \\
\hline 4. & SMAK Kesuma Mataram & Benar & 1 \\
\hline 5. & SMKN 4 Mataram & Benar & 1 \\
\hline 6. & SMK Muhammadiyah Mataram & Benar & 1 \\
\hline
\end{tabular}

Pemahaman guru bahasa Indonesia SMA, SMK, dan MA di Kota Mataram terhadap jenis teks yaitu mampu memahami jenis teks eksposisi, karena semua responden menjawab dengan benar sehingga semua di beri skor 1 .

Tabel 5 Pemahaman Guru Bahasa Indonesia terhadap Jenis Teks Prosedur dalam Pembelajaran Bahasa Indonesia Berbasis Teks

\begin{tabular}{|c|l|c|c|}
\hline No & \multicolumn{1}{|c|}{ Nama Sekolah } & $\begin{array}{c}\text { Jawaban } \\
\text { responden }\end{array}$ & Skor \\
\hline 1. & MAN 1 Mataram & Benar & 1 \\
\hline 2. & MA Hidayatullah Mataram & Benar & 1 \\
\hline 3. & SMAN 1 Mataram & Benar & 1 \\
\hline 4. & SMAK Kesuma Mataram & Benar & 1 \\
\hline 5. & SMKN 4 Mataram & Benar & 1 \\
\hline 6. & SMK Muhammadiyah Mataram & Benar & 1 \\
\hline
\end{tabular}

Pemahaman guru bahasa Indonesia SMA, SMK, dan MA di Kota Mataram terhadap jenis teks yaitu mampu memahami jenis teks prosedur, karena semua responden menjawab dengan benar sehingga semua di beri skor 1 .

\section{Pemahaman guru bahasa Indonesia terhadap} struktur teks berdasarkan genrenya

Berdasarkan hasil pengumpulan data bahwa pemahaman guru bahasa Indonesia terhadap struktur teks cerpen, eksposisi, dan prosedur maka, diperoleh data sebagai berikut.

Tabel 6 Pemahaman Guru Bahasa Indonesia terhadap Struktur Teks Cerpen dalam Pembelajaran Bahasa Indonesia Berbasis Teks

\begin{tabular}{|l|l|c|c|}
\hline $\begin{array}{l}\text { No } \\
.\end{array}$ & \multicolumn{1}{|c|}{ Nama Sekolah } & $\begin{array}{c}\text { Jawaban } \\
\text { responden }\end{array}$ & Skor \\
\hline 1. & MAN 1 Mataram & Benar & 3 \\
\hline 2. & MA Hidayatullah Mataram & Benar & 3 \\
\hline 3. & SMAN 1 Mataram & Benar & 3 \\
\hline 4. & SMAK Kesuma Mataram & Benar & 3 \\
\hline 5. & SMKN 4 Mataram & Benar & 3 \\
\hline 6. & SMK Muhammadiyah Mataram & Benar & 3 \\
\hline
\end{tabular}

Data di atas merupakan hasil rekapitulasi dari responden untuk menjawab tentang struktur 
teks yang berupa struktur teks cerpen dan jawaban-jawaban itu tertera pada tabel 4. Jika dicermati pada tabel di atas dari enam responden menunjukkan bahwa responden menjawab dengan benar sehingga semua di beri skor 3 .

Tabel 7 Pemahaman Guru Bahasa Indonesia terhadap Struktur Teks Eksposisi dalam Pembelajaran Bahasa Indonesia Berbasis Teks

\begin{tabular}{|l|l|c|c|}
\hline No & \multicolumn{1}{|c|}{ Nama Sekolah } & $\begin{array}{c}\text { Jawaban } \\
\text { responden }\end{array}$ & Skor \\
\hline 1. & MAN 1 Mataram & Benar & 3 \\
\hline 2. & MA Hidayatullah Mataram & Benar & 3 \\
\hline 3. & SMAN 1 Mataram & Benar & 3 \\
\hline 4. & SMAK Kesuma Mataram & Benar & 3 \\
\hline 5. & SMKN 4 Mataram & Benar & 3 \\
\hline 6. & SMK Muhammadiyah Mataram & Benar & 3 \\
\hline
\end{tabular}

Berdasarkan tabel di atas, pemahaman guru bahasa Indonesia SMA, SMK, dan MA di Kota Mataram terhadap struktur teks yaitu mampu memahami struktur teks eksposisi, karena semua responden menjawab dengan benar sehingga semua di beri skor 3 .

Tabel 8 Pemahaman Guru Bahasa Indonesia terhadap Struktur Teks Prosedur dalam Pembelajaran Bahasa Indonesia Berbasis Teks

\begin{tabular}{|l|l|c|c|}
\hline $\begin{array}{l}\text { No } \\
.\end{array}$ & \multicolumn{1}{|c|}{ Nama Sekolah } & $\begin{array}{c}\text { Jawaban } \\
\text { responden }\end{array}$ & Skor \\
\hline 1. & MAN 1 Mataram & Benar & 3 \\
\hline 2. & MA Hidayatullah Mataram & Benar & 3 \\
\hline 3. & SMAN 1 Mataram & Benar & 3 \\
\hline 4. & SMAK Kesuma Mataram & Benar & 3 \\
\hline 5. & SMKN 4 Mataram & Benar & 3 \\
\hline 6. & SMK Muhammadiyah Mataram & Benar & 3 \\
\hline
\end{tabular}

Berdasarkan tabel di atas, pemahaman guru bahasa Indonesia SMA, SMK, dan MA di Kota Mataram terhadap struktur teks yaitu mampu memahami struktur teks prosedur, karena semua responden menjawab dengan benar sehingga semua di beri skor 3 .

\section{Pemahaman guru bahasa Indonesia terhadap penggunaan piranti kebahasaan berdasarkan genrenya}

Pemahaman guru bahasa Indonesia SMA, SMK, dan MA di Kota Mataram terhadap penggunaan piranti kebahasaan teks mencakup 3 jenis yaitu cerpen, eksposisi, dan prosedur.

Berdasarkan hasil pengumpulan data bahwa pemahaman guru bahasa Indonesia terhadap jenis teks cerpen, eksposisi, dan prosedur maka, diperoleh data sebagai berikut.

Tabel 9 Pemahaman Guru Bahasa Indonesia Terhadap Penggunaan Piranti Kebahasaan Teks Cerpen dalam Pembelajaran Bahasa Indonesia Berbasis Teks

\begin{tabular}{|c|c|c|c|c|c|}
\hline No & $\begin{array}{l}\text { Nama } \\
\text { Sekolah }\end{array}$ & Pendeskripsian & $\begin{array}{l}\text { Penila } \\
\text { ian }\end{array}$ & $\begin{array}{l}\text { Jawaban } \\
\text { responden }\end{array}$ & $\begin{array}{l}\text { Sk } \\
\text { or }\end{array}$ \\
\hline \multirow[t]{16}{*}{1.} & \multirow{16}{*}{$\begin{array}{l}\text { MAN } 1 \\
\text { Mataram }\end{array}$} & \multicolumn{4}{|c|}{ Penggunaan piranti penghubung intrakalimat } \\
\hline & & Konjungsi kesetaraan & 2 & Kurang & \multirow{15}{*}{1} \\
\hline & & $\begin{array}{l}\text { Konjungsi } \\
\text { kebertingkatan }\end{array}$ & 1 & Kurang & \\
\hline & & \multicolumn{3}{|c|}{$\begin{array}{l}\text { Penggunaan piranti penghubung } \\
\text { antarkalimat }\end{array}$} & \\
\hline & & $\begin{array}{ll}\text { a. } & \text { Repetisi } \\
\text { bentuk } & \\
\end{array}$ & 1 & Salah & \\
\hline & & $\begin{array}{l}\text { b. } \quad \text { Repetisi } \\
\text { makna/sinonimi }\end{array}$ & - & - & \\
\hline & & $\begin{array}{l}\text { c. Penggunaa } \\
\mathrm{n} \text { anaphora/katafora }\end{array}$ & - & - & \\
\hline & & d. $\quad$ Antonim & - & - & \\
\hline & & $\begin{array}{l}\text { e. Konjungsi/ } \\
\text { kata atau frase } \\
\text { penghubung }\end{array}$ & - & - & \\
\hline & & \multicolumn{3}{|c|}{$\begin{array}{l}\text { Penggunaan Piranti Penghubung Antar } \\
\text { Paragraf }\end{array}$} & \\
\hline & & a. Repetisi bentuk & - & - & \\
\hline & & $\begin{array}{ll}\text { b. } & \text { Repetisi } \\
\text { makna/sinonimi }\end{array}$ & - & - & \\
\hline & & c. Anaphora/katafora & - & - & \\
\hline & & d. Antonim & - & - & \\
\hline & & e. $\quad$ Hiponimi & - & - & \\
\hline & & $\begin{array}{l}\text { f. Konjungsi/kata atau } \\
\text { frase penghubung }\end{array}$ & 1 & Kurang & \\
\hline \multirow{16}{*}{2.} & \multirow{16}{*}{$\begin{array}{l}\text { MA } \\
\text { Hidayatull } \\
\text { ah } \\
\text { Mataram }\end{array}$} & \multicolumn{4}{|c|}{ Penggunaan piranti penghubung intrakalimat } \\
\hline & & Konjungsi kesetaraan & 2 & Kurang & \multirow[t]{15}{*}{3} \\
\hline & & $\begin{array}{l}\text { Konjungsi } \\
\text { kebertingkatan }\end{array}$ & 1 & Kurang & \\
\hline & & $\begin{array}{l}\text { Penggunaan piranti per } \\
\text { antarkalimat }\end{array}$ & hubung & & \\
\hline & & a. Repetisi bentuk & - & - & \\
\hline & & $\begin{array}{l}\text { b. Repetisi } \\
\text { makna/sinonimi }\end{array}$ & - & - & \\
\hline & & $\begin{array}{l}\text { c. Penggunaan } \\
\text { anaphora/katafora }\end{array}$ & - & - & \\
\hline & & d. Antonim & - & - & \\
\hline & & $\begin{array}{l}\text { e. Konjungsi/kata atau } \\
\text { frase penghubung }\end{array}$ & 3 & Kurang & \\
\hline & & \multicolumn{3}{|c|}{$\begin{array}{l}\text { Penggunaan Piranti Penghubung Antar } \\
\text { Paragraf }\end{array}$} & \\
\hline & & a. Repetisi bentuk & - & - & \\
\hline & & $\begin{array}{l}\text { b. Repetisi } \\
\text { makna/sinonimi }\end{array}$ & - & - & \\
\hline & & c. Anaphora/katafora & - & - & \\
\hline & & d. Antonim & - & - & \\
\hline & & e. Hiponimi & - & - & \\
\hline & & $\begin{array}{ll}\text { f. } & \text { Konjungsi/kata atau } \\
\text { frase penghubung }\end{array}$ & 2 & Kurang & \\
\hline \multirow[t]{16}{*}{3.} & \multirow{16}{*}{$\begin{array}{l}\text { SMAN 1 } \\
\text { Mataram }\end{array}$} & \multicolumn{3}{|c|}{ Penggunaan piranti penghubung intrakalimat } & \multirow[t]{16}{*}{2} \\
\hline & & $\begin{array}{l}\text { a. Konjungsi } \\
\text { kesetaraan }\end{array}$ & 4 & Kurang & \\
\hline & & $\begin{array}{l}\text { b. Konjungsi } \\
\text { kebertingkatan }\end{array}$ & 7 & Kurang & \\
\hline & & $\begin{array}{l}\text { Penggunaan piranti per } \\
\text { antarkalimat }\end{array}$ & hubung & & \\
\hline & & a. Repetisi bentuk & 2 & Salah & \\
\hline & & $\begin{array}{l}\text { b. Repetisi } \\
\text { makna/sinonimi }\end{array}$ & - & - & \\
\hline & & $\begin{array}{l}\text { c. Penggunaan } \\
\text { anaphora/katafora }\end{array}$ & - & - & \\
\hline & & d. Antonim & - & - & \\
\hline & & $\begin{array}{l}\text { e. Konjungsi/kata atau } \\
\text { frase penghubung }\end{array}$ & 6 & Kurang & \\
\hline & & \multicolumn{3}{|c|}{$\begin{array}{l}\text { Penggunaan Piranti Penghubung Antar } \\
\text { Paragraf }\end{array}$} & \\
\hline & & a. $\quad$ Repetisi bentuk & - & - & \\
\hline & & $\begin{array}{ll}\text { b. } & \text { Repetisi } \\
& \text { makna/sinonimi }\end{array}$ & - & - & \\
\hline & & c. Anaphora/katafora & - & - & \\
\hline & & d. Antonim & - & - & \\
\hline & & e. Hiponimi & - & - & \\
\hline & & $\begin{array}{ll}\text { f. } & \text { Konjungsi/kata atau } \\
\text { frase penghubung }\end{array}$ & 3 & Kurang & \\
\hline \multirow[t]{3}{*}{4.} & \multirow{3}{*}{$\begin{array}{l}\text { SMAK } \\
\text { Kesuma } \\
\text { Mataram }\end{array}$} & \multicolumn{3}{|c|}{ Penggunaan piranti penghubung intrakalimat } & 1 \\
\hline & & $\begin{array}{l}\text { a. Konjungsi } \\
\text { kesetaraan }\end{array}$ & 2 & Kurang & \\
\hline & & $\begin{array}{l}\text { b. Konjungsi } \\
\text { kebertingkatan }\end{array}$ & 1 & Kurang & \\
\hline
\end{tabular}




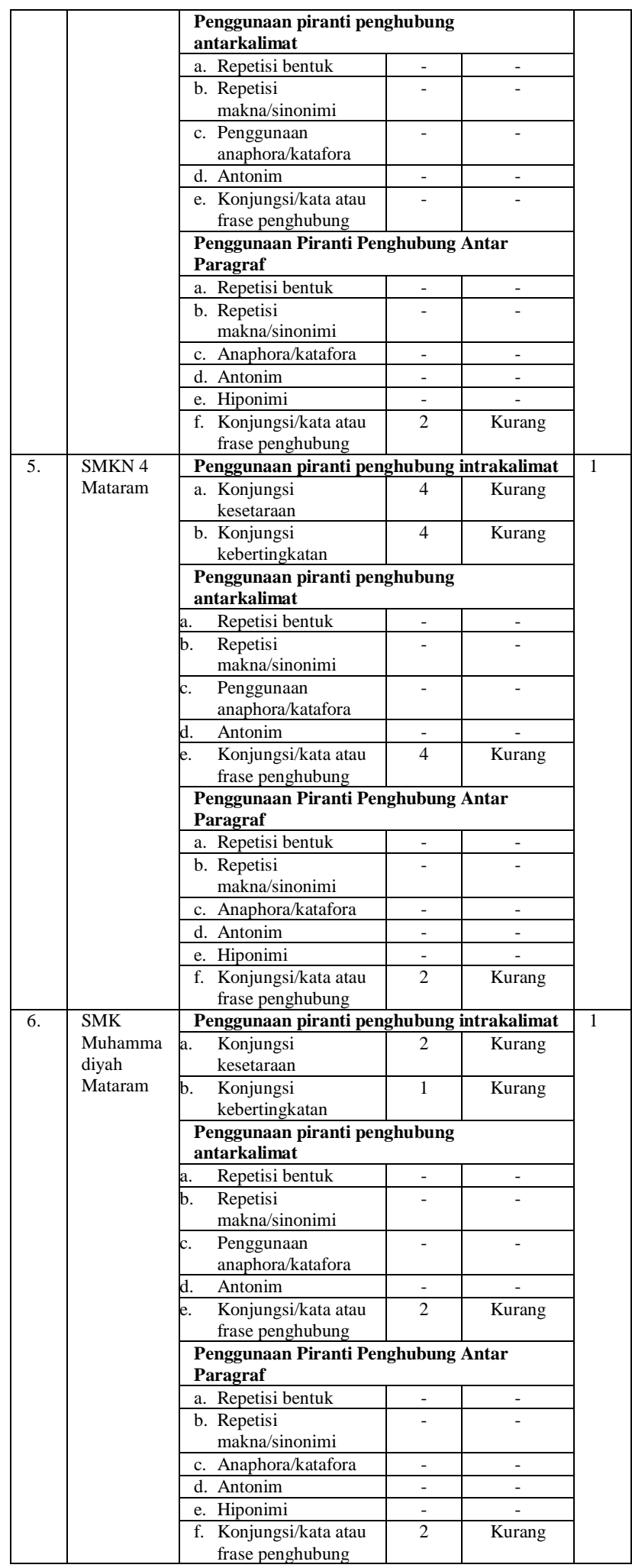

Data di atas merupakan hasil rekapitulasi dari responden yang dimana setiap sekolah diambil satu responden untuk menjawab tentang penggunaan piranti kebahasaan dalam teks cerpen dan jawaban-jawaban itu tertera pada tabel 7. Jika dicermati pada tabel di atas dari enam responden menunjukkan bahwa responden kurang mampu menjawab dengan benar sehingga setiap responden mendapatkan skor 1, 2, dan 3. Sedangkan untuk tanda strip (-) pada tabel jawaban responden di atas merupakan sebagian besar memang tidak ada dalam teks cerpen.

Tabel 10 Pemahaman Guru Bahasa Indonesia terhadap Penggunaan Piranti Kebahasaan Teks Eksposisi dalam Pembelajaran Bahasa Indonesia Berbasis Teks

\begin{tabular}{|c|c|c|c|c|c|}
\hline No. & $\begin{array}{c}\text { Nama } \\
\text { Sekolah }\end{array}$ & Pendeskripsian & $\begin{array}{c}\text { Penilaia } \\
n\end{array}$ & $\begin{array}{c}\text { Jawaban } \\
\text { responden }\end{array}$ & Skor \\
\hline & \multirow[t]{16}{*}{$\begin{array}{l}\text { MAN } 1 \\
\text { Mataram }\end{array}$} & \multicolumn{3}{|c|}{$\begin{array}{l}\text { Penggunaan piranti penghubung } \\
\text { intrakalimat }\end{array}$} & \multirow[t]{16}{*}{2} \\
\hline & & \begin{tabular}{|l|} 
Konjungsi \\
kesetaraan
\end{tabular} & 1 & Kurang & \\
\hline & & 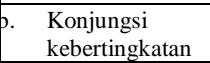 & 1 & Kurang & \\
\hline & & \multicolumn{3}{|c|}{$\begin{array}{l}\text { Penggunaan piranti penghubung } \\
\text { antarkalimat }\end{array}$} & \\
\hline & & 2. Repetisi bentuk & 2 & Kurang & \\
\hline & & $\begin{array}{ll}\text {. Repetisi } \\
\text { makna/sinonim } \\
\mathrm{i}\end{array}$ & 2 & Kurang & \\
\hline & & $\begin{array}{l}\text { Penggunaan } \\
\text { anaphora/kataf } \\
\text { ora }\end{array}$ & - & - & \\
\hline & & 1. Antonim & - & - & \\
\hline & & $\begin{array}{l}\text { Konjungsi/kata } \\
\text { atau frase } \\
\text { penghubung }\end{array}$ & - & - & \\
\hline & & \multicolumn{3}{|c|}{$\begin{array}{l}\text { Penggunaan Piranti Penghubung Antar } \\
\text { Paragraf }\end{array}$} & \\
\hline & & a. Repetisi bentuk & 1 & Kurang & \\
\hline & & $\begin{array}{l}\text { b. Repetisi } \\
\text { makna/sinonim } \\
\mathrm{i} \\
\end{array}$ & 1 & - & \\
\hline & & $\begin{array}{l}\text { c. Anaphora/kataf } \\
\text { ora }\end{array}$ & - & - & \\
\hline & & d. Antonim & - & - & \\
\hline & & e. Hiponimi & - & - & \\
\hline & & 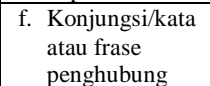 & 1 & Kurang & \\
\hline \multirow[t]{16}{*}{2.} & \multirow{16}{*}{$\begin{array}{l}\text { MA } \\
\text { Hidayatull } \\
\text { ah } \\
\text { Mataram }\end{array}$} & \multicolumn{3}{|c|}{$\begin{array}{l}\text { Penggunaan piranti penghubung } \\
\text { intrakalimat }\end{array}$} & \multirow[t]{16}{*}{1} \\
\hline & & $\begin{array}{l}\text { a. Konjungsi } \\
\text { kesetaraan }\end{array}$ & 4 & Kurang & \\
\hline & & $\begin{array}{l}\text { b. Konjungsi } \\
\text { kebertingkatan }\end{array}$ & 3 & Kurang & \\
\hline & & \multicolumn{3}{|c|}{$\begin{array}{l}\text { Penggunaan piranti penghubung } \\
\text { antarkalimat }\end{array}$} & \\
\hline & & a. Repetisi bentuk & - & - & \\
\hline & & $\begin{array}{l}\text { b. Repetisi } \\
\text { makna/sinonim } \\
\text { i }\end{array}$ & - & - & \\
\hline & & \begin{tabular}{|l} 
c. Penggunaan \\
anaphora/kataf \\
ora
\end{tabular} & - & - & \\
\hline & & d. Antonim & - & - & \\
\hline & & $\begin{array}{l}\text { e. Konjungsi/kata } \\
\text { atau frase } \\
\text { penghubung }\end{array}$ & 2 & Kurang & \\
\hline & & \multicolumn{3}{|c|}{$\begin{array}{l}\text { Penggunaan Piranti Penghubung Antar } \\
\text { Paragraf }\end{array}$} & \\
\hline & & a. Repetisi bentuk & - & - & \\
\hline & & $\begin{array}{l}\text { b. Repetisi } \\
\text { makna/sinonim } \\
\text { i }\end{array}$ & - & - & \\
\hline & & $\begin{array}{l}\text { c. Anaphora/kataf } \\
\text { ora }\end{array}$ & - & - & \\
\hline & & d. Antonim & - & - & \\
\hline & & e. Hiponimi & - & - & \\
\hline & & $\begin{array}{l}\text { f. Konjungsi/kata } \\
\text { atau frase } \\
\text { penghubung }\end{array}$ & 1 & Kurang & \\
\hline \multirow[t]{2}{*}{3.} & $\begin{array}{l}\text { SMAN } 1 \\
\text { Mataram }\end{array}$ & \multicolumn{3}{|c|}{$\begin{array}{l}\text { Penggunaan piranti penghubung } \\
\text { intrakalimat }\end{array}$} & \multirow[t]{2}{*}{2} \\
\hline & & i. Konjungsi & 3 & Kurang & \\
\hline
\end{tabular}


Terakreditasi Peringkat 5 (No. SK: 85/M/KPT/2020)

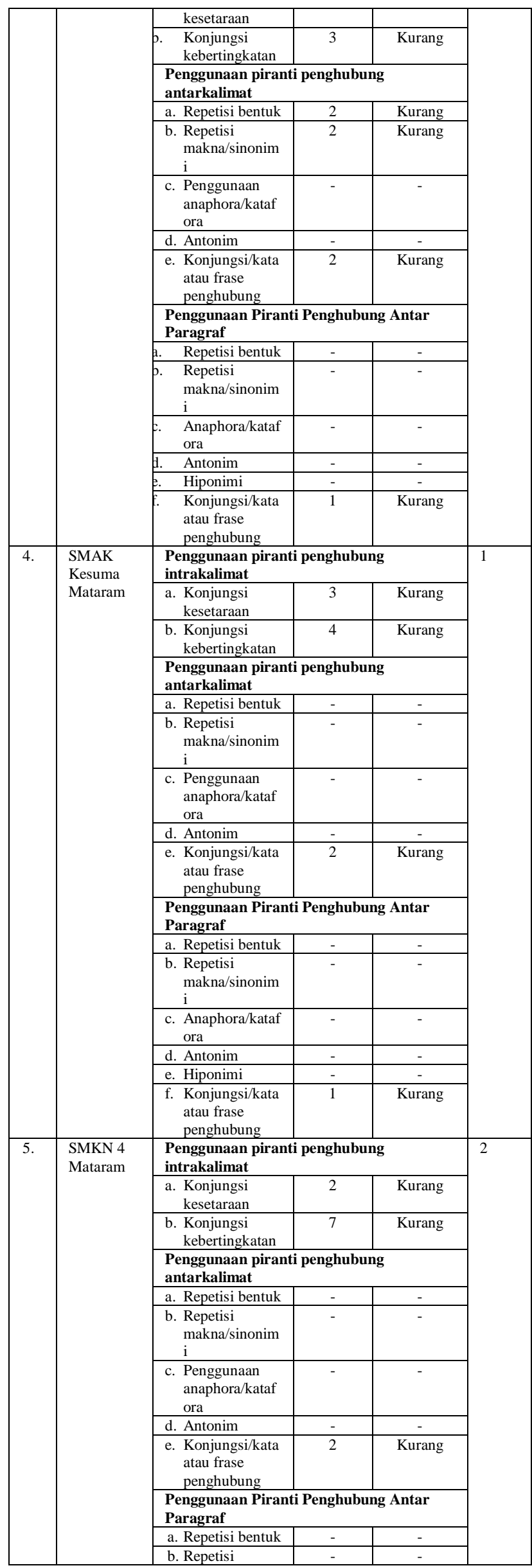

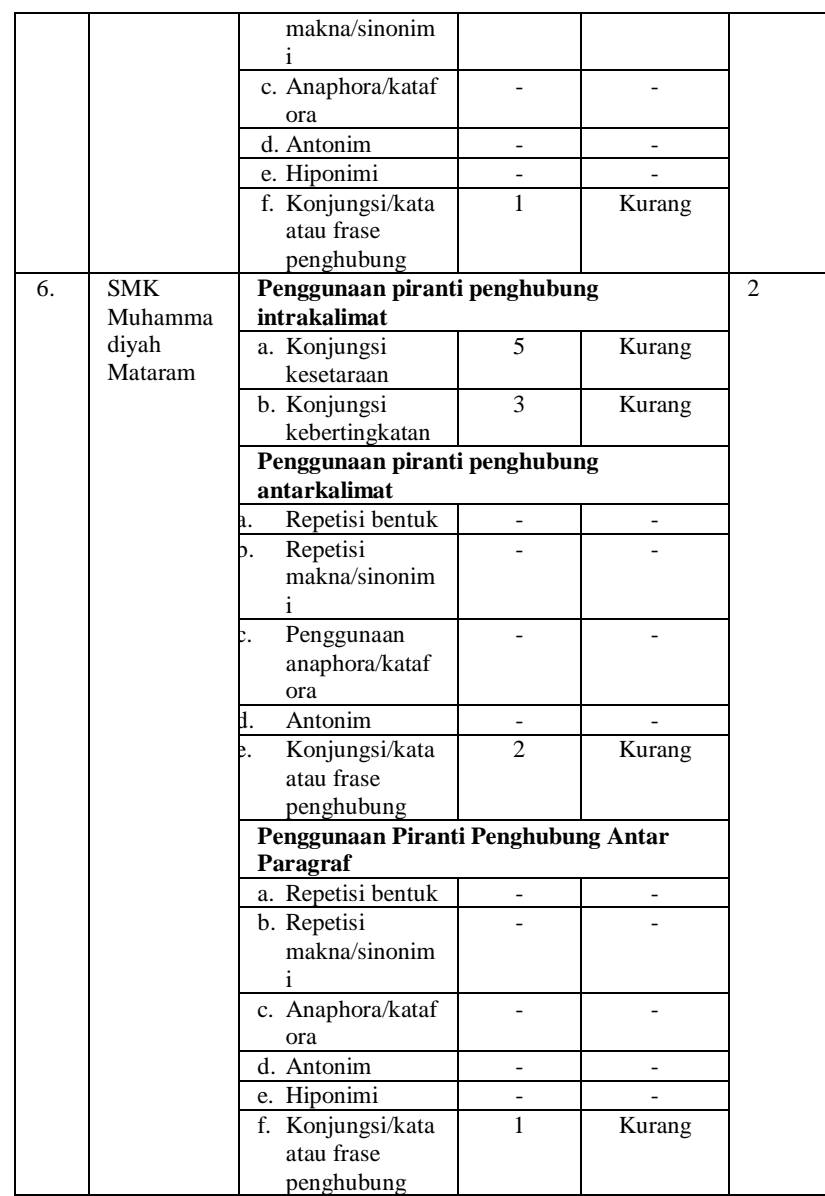

Berdasarkan data di atas responden menjawab tentang penggunaan piranti kebahasaan dalam teks eksposisi dan jawabanjawaban itu tertera pada tabel 8 di atas. Jika dicermati pada tabel di atas dari enam responden menunjukkan bahwa responden kurang mampu menjawab dengan benar sehingga setiap responden mendapatkan skor 1, dan 2 . Sedangkan untuk tanda strip (-) pada tabel jawaban responden di atas merupakan sebagian kecil memang tidak ada dalam teks eksposisi.

Tabel 11 Pemahaman Guru Bahasa Indonesia terhadap Penggunaan Piranti Kebahasaan Teks Prosedur dalam Pembelajaran Bahasa Indonesia Berbasis Teks

\begin{tabular}{|c|c|c|c|c|c|}
\hline No. & $\begin{array}{l}\text { Nama } \\
\text { Sekolah }\end{array}$ & Pendeskripsian & $\begin{array}{l}\text { Penila } \\
\text { ian }\end{array}$ & $\begin{array}{l}\text { Jawaban } \\
\text { respond } \\
\text { en }\end{array}$ & Skor \\
\hline \multirow[t]{8}{*}{1.} & \multirow[t]{8}{*}{$\begin{array}{l}\text { MAN } 1 \\
\text { Mataram }\end{array}$} & \multicolumn{3}{|c|}{$\begin{array}{l}\text { Penggunaan piranti penghubung } \\
\text { intrakalimat }\end{array}$} & \multirow[t]{8}{*}{3} \\
\hline & & $\begin{array}{ll}\text { a. } & \text { Konjungsi } \\
\text { kesetaraan }\end{array}$ & 2 & Kurang & \\
\hline & & $\begin{array}{l}\text { b. Konjungsi } \\
\text { kebertingkatan }\end{array}$ & 2 & Benar & \\
\hline & & \multicolumn{3}{|c|}{$\begin{array}{l}\text { Penggunaan piranti penghubung } \\
\text { antarkalimat }\end{array}$} & \\
\hline & & 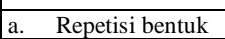 & 1 & Kurang & \\
\hline & & $\begin{array}{|ll|}\text { b. } & \text { Repetisi } \\
& \text { makna/sinonimi }\end{array}$ & 2 & Benar & \\
\hline & & 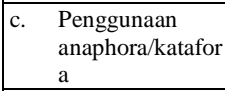 & - & - & \\
\hline & & \begin{tabular}{|ll} 
d. & Antonim \\
\end{tabular} & - & - & \\
\hline
\end{tabular}


Jurnal Ilmu Sosial dan Pendidikan

Vol. 4. No. 3 Juli 2020

http://ejournal.mandalanursa.org/index.php/JISIP/index

-9944 e- ISSN: $2656-6753$

Terakreditasi Peringkat 5 (No. SK: 85/M/KPT/2020)

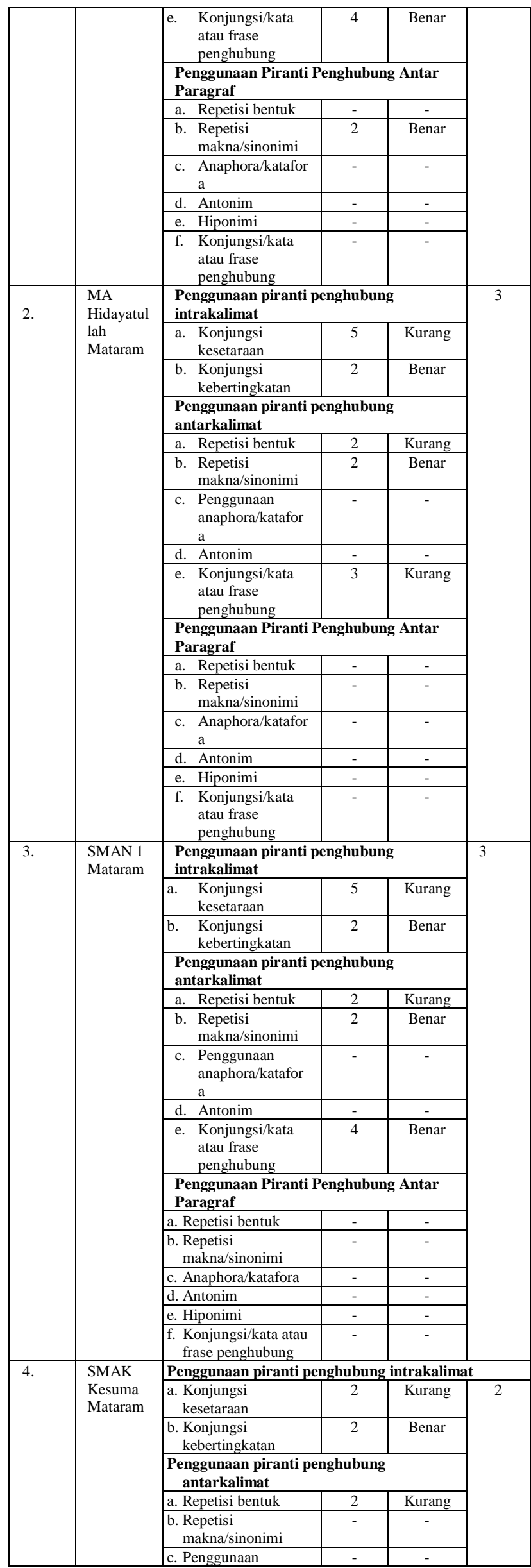

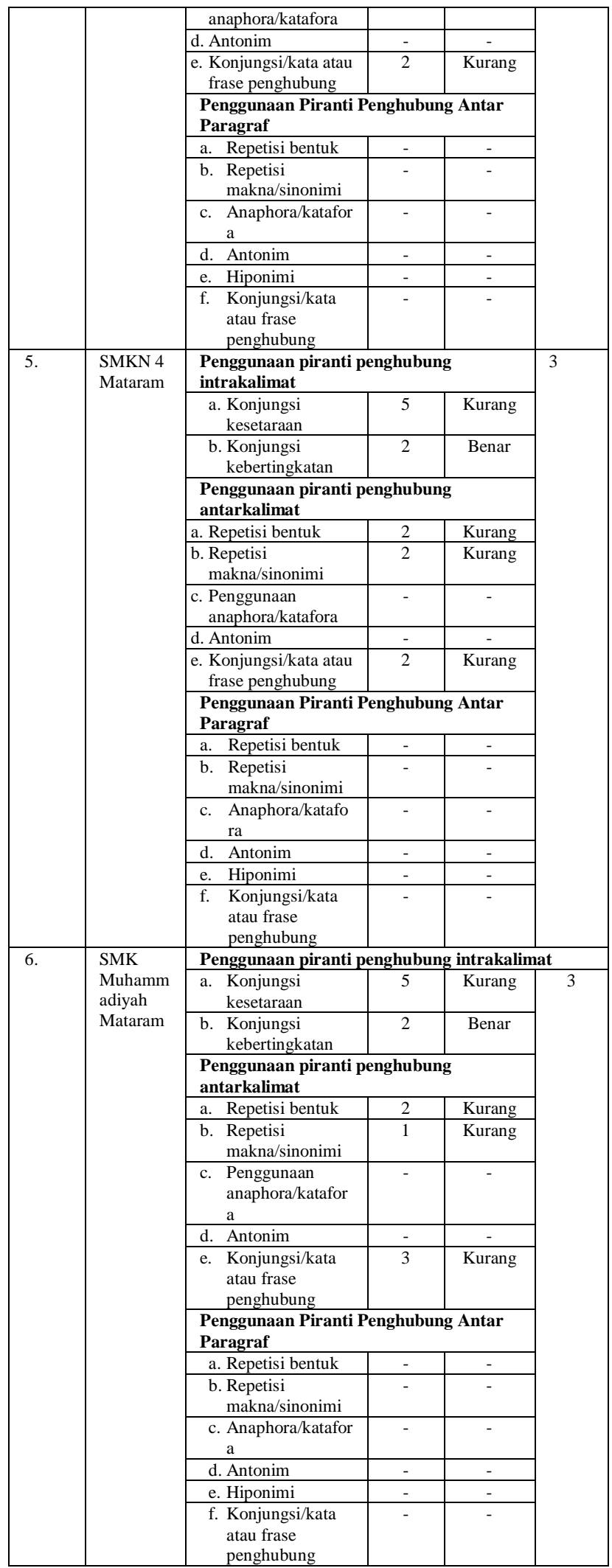

Berdasarkan data di atas responden menjawab tentang penggunaan piranti kebahasaan dalam teks prosedur dan jawabanjawaban itu tertera pada tabel 9. Jika dicermati pada tabel di atas dari enam responden menunjukkan bahwa responden kurang mampu 
menjawab dengan benar sehingga setiap responden mendapatkan skor 2 sampai 3 . Sedangkan untuk tanda strip (-) pada tabel jawaban responden di atas merupakan sebagian kecil memang tidak ada dalam teks prosedur.

Pemahaman guru bahasa Indonesia terhadap tujuan sosial teks sesuai dengan genrenya

Pemahaman guru bahasa Indonesia SMA, SMK, dan MA di Kota Mataram terhadap penggunaan piranti kebahasaan teks mencakup 3 jenis yaitu cerpen, eksposisi, dan prosedur.

Berdasarkan hasil pengumpulan data bahwa pemahaman guru bahasa Indonesia terhadap tujuan sosial teks cerpen, eksposisi, dan prosedur maka, diperoleh data sebagai berikut.

Tabel 12 Pemahaman Guru Bahasa Indonesia terhadap Tujuan Sosial Teks Cerpen dalam Pembelajaran Bahasa Indonesia Berbasis Teks

\begin{tabular}{|l|l|c|c|}
\hline No. & \multicolumn{1}{|c|}{ Nama Sekolah } & Status & Skor \\
\hline 1. & MAN 1 Mataram & Benar & 2 \\
\hline 2. & MA Hidayatullah Mataram & Benar & 2 \\
\hline 3. & SMAN 1 Mataram & Benar & 2 \\
\hline 4. & SMAK Kesuma Mataram & Benar & 2 \\
\hline 5. & SMKN 4 Mataram & Benar & 2 \\
\hline 6. & SMK Muhammadiyah Mataram & Benar & 2 \\
\hline
\end{tabular}

Pemahaman guru bahasa Indonesia SMA, SMK, dan MA di Kota Mataram terhadap tujuan sosial dalam teks cerpen yaitu mampu memahami tujuan sosial, karena semua responden mampu mendeskripsikan pemahamannya dalam teks cerpen.

Tabel 13 Pemahaman Guru Bahasa Indonesia terhadap Tujuan Sosial Teks Eksposisi dalam Pembelajaran Bahasa Indonesia Berbasis Teks

\begin{tabular}{|c|c|c|c|}
\hline No. & Nama Sekolah & Status & Skor \\
\hline 1. & MAN 1 Mataram & Benar & 2 \\
\hline 2. & MA Hidayatullah Mataram & Benar & 2 \\
\hline 3. & SMAN 1 Mataram & Benar & 2 \\
\hline 4. & SMAK Kesuma Mataram & Benar & 2 \\
\hline 5. & SMKN 4 Mataram & Benar & 2 \\
\hline 6. & SMK Muhammadiyah Mataram & Benar & 2 \\
\hline
\end{tabular}

SMA, SMK, dan MA di Kota Mataram terhadap tujuan sosial dalam teks eksposisi yaitu mampu memahami tujuan sosial, karena semua responden mampu mendeskripsikan pemahamannya dalam teks eksposisi.

Tabel 14 Pemahaman Guru Bahasa Indonesia terhadap Tujuan Sosial Teks Prosedur dalam Pembelajaran Bahasa Indonesia Berbasis Teks

\begin{tabular}{|c|l|c|c|}
\hline No. & \multicolumn{1}{|c|}{ Nama Sekolah } & Status & Skor \\
\hline 1. & MAN 1 Mataram & Benar & 2 \\
\hline 2. & MA Hidayatullah Mataram & Benar & 2 \\
\hline
\end{tabular}

\begin{tabular}{|l|l|l|l|}
\hline 3. & SMAN 1 Mataram & Benar & 2 \\
\hline 4. & SMAK Kesuma Mataram & Benar & 2 \\
\hline 5. & SMKN 4 Mataram & Benar & 2 \\
\hline 6. & SMK Muhammadiyah Mataram & Benar & 2 \\
\hline
\end{tabular}

Pemahaman guru bahasa Indonesia SMA, SMK, dan MA di Kota Mataram terhadap tujuan sosial dalam teks prosedur yaitu mampu memahami tujuan sosial, karena semua responden mampu mendeskripsikan pemahamannya dalam teks prosedur.

\section{Pembahasan}

Berdasarkan hasil penelitian yang diuraikan pada subbab 4.1 terhadap keempat aspek tersebut dapat dijelaskan sebagai berikut.

\section{Pemahaman guru bahasa Indonesia terhadap} jenis teks berdasarkan genrenya

Berdasarkan hasil penelitian yang diuraikan pada subbab 4.1.1 tentang pemahaman guru bahasa Indonesia terhadap jenis teks cerpen, eksposisi, dan prosedur dapat dikemukakan sebagai berikut.

Mengenai pemahaman guru bahasa Indonesia terhadap jenis teks cerpen terurai pada tabel 3 . Jika dicermati tabel tersebut dapat dikatakan bahwa guru SMA, SMK, dan MA di Kota Mataram memahami jenis teks cerpen. Dengan kata lain, para guru tersebut mampu mengidentifikasi atau membedakan jenis teks cerpen atau bukan. Hal ini ditandai oleh kemampuan menjawab teks yang diberikan pada responden.

Pemahaman guru bahasa Indonesia terhadap jenis teks eksposisi terurai pada tabel 4. Jika dicermati tabel tersebut dapat dikatakan bahwa guru SMA, SMK, dan MA di Kota Mataram memahami jenis teks eksposisi. Dengan kata lain, para guru tersebut mampu mengidentifikasi atau membedakan jenis teks eksposisi atau bukan. Hal ini ditandai oleh kemampuan menjawab teks yang diberikan pada responden.

Selanjutnya, pemahaman guru bahasa Indonesia terhadap jenis teks prosedur terurai pada tabel 5 . Jika dicermati tabel tersebut dapat dikatakan bahwa guru SMA, SMK, dan MA di Kota Mataram memahami jenis teks prosedur. Dengan kata lain, para guru tersebut mampu mengidentifikasi atau membedakan jenis teks prosedur atau bukan. Hal ini ditandai oleh kemampuan menjawab teks yang diberikan pada responden. 
Jadi, pemahaman guru bahasa Indonesia SMA, SMK, dan MA di Kota Mataram terhadap jenis teks cerpen, eksposisi, dan prosedur dapat dikatakan mampu karena semua responden mampu memahami jenis-jenis teks yang telah ditentukan.

Pemahaman guru bahasa Indonesia terhadap struktur teks berdasarkan genrenya

Berdasarkan hasil penelitian yang diuraikan pada subbab 4.1.2 tentang pemahaman guru bahasa Indonesia terhadap struktur teks cerpen, eksposisi, dan prosedur dapat dikemukakan sebagai berikut.

Mengenai pemahaman guru bahasa Indonesia terhadap struktur teks cerpen terurai pada tabel 6. Jika dicermati tabel tersebut dapat dikatakan bahwa guru SMA, SMK, dan MA di Kota Mataram memahami struktur teks cerpen. Dengan kata lain, para guru tersebut mampu mengidentifikasi atau membedakan struktur teks cerpen atau bukan. Hal ini ditandai oleh kemampuan menjawab teks yang diberikan pada responden.

Pemahaman guru bahasa Indonesia terhadap struktur teks eksposisi terurai pada tabel 7. Jika dicermati tabel tersebut dapat dikatakan bahwa guru SMA, SMK, dan MA di Kota Mataram memahami struktur teks eksposisi. Dengan kata lain, para guru tersebut mampu mengidentifikasi atau membedakan struktur teks eksposisi atau bukan. Hal ini ditandai oleh kemampuan menjawab teks yang diberikan pada responden.

Selanjutnya, pemahaman guru bahasa Indonesia terhadap struktur teks prosedur terurai pada tabel 8. Jika dicermati tabel tersebut dapat dikatakan bahwa guru SMA, SMK, dan MA di Kota Mataram memahami struktur teks prosedur. Dengan kata lain, para guru tersebut mampu mengidentifikasi atau membedakan struktur teks prosedur atau bukan. Hal ini ditandai oleh kemampuan menjawab teks yang diberikan pada responden.

Jadi, dari sudut pandang pemahaman guru bahasa Indonesia SMA, SMK, dan MA di Kota Mataram terhadap pembelajaran bahasa Indonesia berbasis teks mampu memahami struktur teks berdasarkan genrenya.

Pemahaman guru bahasa Indonesia terhadap penggunaan piranti kebahasaan teks berdasarkan genrenya
Berdasarkan hasil penelitian yang diuraikan pada subbab 4.1.3 tentang pemahaman guru bahasa Indonesia terhadap penggunaan piranti kebahasaan teks cerpen, eksposisi, dan prosedur dapat dikemukakan sebagai berikut.

Mengenai pemahaman guru bahasa Indonesia terhadap penggunaan piranti kebahasaan teks cerpen terurai pada tabel 9. Jika dicermati tabel tersebut dapat dikatakan bahwa guru SMA, SMK, dan MA di Kota Mataram kurang memahami penggunaan piranti kebahasaan teks cerpen. Dengan kata lain, para guru tersebut kurang mampu mengidentifikasi atau membedakan penggunaan piranti kebahasaan teks cerpen atau bukan. Hal ini ditandai oleh kemampuan menjawab teks yang diberikan pada responden.

Pemahaman guru bahasa Indonesia terhadap penggunaan piranti kebahasaan teks eksposisi terurai pada tabel 10. Jika dicermati tabel tersebut dapat dikatakan bahwa guru SMA, SMK, dan MA di Kota Mataram kurang memahami penggunaan piranti kebahasaan teks eksposisi. Dengan kata lain, para guru tersebut kurang mampu mengidentifikasi atau membedakan penggunaan piranti kebahasaan teks eksposisi atau bukan. Hal ini ditandai oleh kemampuan menjawab teks yang diberikan pada responden.

Selanjutnya, pemahaman guru bahasa Indonesia terhadap penggunaan piranti kebahasaan teks prosedur terurai pada tabel 11 . Jika dicermati tabel tersebut dapat dikatakan bahwa guru SMA, SMK, dan MA di Kota Mataram kurang memahami penggunaan piranti kebahasaan teks prosedur. Dengan kata lain, para guru tersebut kurang mampu mengidentifikasi atau membedakan penggunaan piranti kebahasaan teks cerpen atau bukan. Hal ini ditandai oleh kemampuan menjawab teks yang diberikan pada responden.

Jadi, pemahaman guru bahasa Indonesia SMA, SMK, dan MA di Kota Mataram terhadap pembelajaran bahasa Indonesia berbasis teks, kurang mampu memahami penggunaan piranti kebahasaan dalam teks berdasarkan genrenya.

Pemahaman guru bahasa Indonesia terhadap tujuan sosial teks berdasarkan genrenya

Berdasarkan data hasil penelitian yang diuraikan pada subbab 4.1.4 tentang 
pemahaman guru bahasa Indonesia terhadap tujuan sosial teks cerpen, eksposisi, dan prosedur dapat dikemukakan sebagai berikut.

Mengenai pemahaman guru bahasa Indonesia terhadap tujuan sosial teks cerpen terurai pada tabel 12. Jika dicermati tabel tersebut dapat dikatakan bahwa guru SMA, SMK, dan MA di Kota Mataram memahami tujuan sosial teks cerpen. Dengan kata lain, para guru tersebut mampu mengidentifikasi atau membedakan tujuan sosial teks cerpen atau bukan. Hal ini ditandai oleh kemampuan menjawab teks yang diberikan pada responden.

Pemahaman guru bahasa Indonesia terhadap tujuan sosial teks eksposisi terurai pada tabel 13. Jika dicermati tabel tersebut dapat dikatakan bahwa guru SMA, SMK, dan MA di Kota Mataram memahami tujuan sosial teks eksposisi. Dengan kata lain, para guru tersebut mampu mengidentifikasi atau membedakan tujuan sosial teks eksposisi atau bukan. Hal ini ditandai oleh kemampuan menjawab teks yang diberikan pada responden.

Selanjutnya, pemahaman guru bahasa Indonesia terhadap tujuan sosial teks prosedur terurai pada tabel 14. Jika dicermati tabel tersebut dapat dikatakan bahwa guru SMA, SMK, dan MA di Kota Mataram memahami tujuan sosial teks prosedur. Dengan kata lain, para guru tersebut mampu mengidentifikasi atau membedakan tujuan sosial teks prosedur atau bukan. Hal ini ditandai oleh kemampuan menjawab teks yang diberikan pada responden.

Jadi, pemahaman guru bahasa Indonesia SMA, SMK, dan MA di Kota Mataram terhadap pembelajaran bahasa Indonesia berbasis teks, mampu memahami tujuan sosial dalam teks berdasarkan genrenya.

\section{SIMPULAN}

Dari hasil penelitian terhadap pemahaman guru bahasa Indonesia SMA, SMK, dan MA di Kota Mataram terhadap pembelajaran bahasa Indonesia berbasis teks maka, dapat disimpulkan sebagai berikut.

a. Pemahaman guru bahasa Indonesia SMA, SMK, dan MA di Kota Mataram terhadap pembelajaran bahasa Indonesia berbasis teks mampu memahami jenis-jenis teks berdasarkan genrenya, karena semua responden mampu mendeskripsikan pemahamannya dalam teks berdasarkan genrenya.

b. Dari sudut pandang pemahaman guru bahasa Indonesia SMA, SMK, dan MA di Kota Mataram terhadap pembelajaran bahasa Indonesia berbasis teks mampu memahami struktur teks berdasarkan genrenya, karena semua responden mampu mendeskripsikan pemahamannya dalam teks itu sendiri.

c. Pemahaman guru bahasa Indonesia SMA, SMK, dan MA di Kota Mataram terhadap pembelajaran bahasa Indonesia berbasis teks kurang mampu memahami penggunaan piranti kebahasaan dalam teks, karena sebagian besar responden kurang mampu mendeskripsikan pemahamannya dalam teks berdasarkan genrenya.

d. Dan terakhir, pemahaman guru bahasa Indonesia SMA, SMK, dan MA di Kota Mataram terhadap pembelajaran bahasa Indonesia berbasis teks di Kota Mataram mampu memahami tujuan sosial dalam teks, karena semua responden mampu mendeskripsikan pemahamannya dalam teks berdasarkan genrenya.

\section{SARAN}

1. Diharapkan kepada pihak yang terkait langsung dalam proses pembelajaran bahasa Indonesia berbasis teks agar lebih aktif dalam membimbing siswa sehingga hasil belajar yang diperoleh lebih meningkat.

2. Sekolah harus berusaha dengan berbagai kebijaksanaan untuk dapat menjadikan sekolah sebagai pusat pengembangan minat dan kegemaran siswa antara lain dengan melengkapi perpustakaan dengan bukubuku bacaan baik buku mata pelajaran maupun buku-buku cerita lainnya dan berusaha mengadakan kegiatan-kegiatan perlombaan pada umumnya, supaya kemampuan siswa-siswa semakin meningkat.

3. Hasil penelitian ini diharapkan dapat digunakan untuk mengembangkan pemahaman informasi oleh guru dalam proses belajar mengajar, memperbaiki kekurangan yang ada dalam kegiatan pembelajaran dan memberikan gagasan untuk peningkatan kearah yang lebih baik. 
4. Berdasarkan hasil penelitian ini dapat menjadi pedoman bagi pihak-pihak yang menentukan kebijaksanaan ke depan dalam menentukan program untuk mengembangkan dan menanamkan minat dan kegemaran kualitas sumber daya manusia.

\section{DAFTAR PUSTAKA}

Afrila, dkk. (2018). Implementasi Pembelajaran Bahasa Indonesia Berbasis Teks Di SMP Negeri Kota Bukittinggi. Skripsi. Universitas Negeri Padang. Diakses Melalui Internet Pada Hari Kamis, 05 September 2019. http://repository.unp.ac.id/id/eprint/1952 1 .

Arikunto. 2010. Prosedur Penelitian. Jakarta: Rineka Cipta

Bintari, dkk. 2014. Pembelajaran Bahasa Indonesia Berdasarkan Pendekatan Saintifik (Problem Based Learning) Sesuai Kurikulum 2013 Di Kelas VII SMP Negeri 2 Amlapura. E-journal Program Pascasarjana Universitas Pendidikan Ganesha. Program Studi Pendidikan Bahasa dan Sastra Indonesia, Undiksha. Vol. 1 No. 1. 2014.

Christie, F. 1999. "Genre Theory and ESL Teaching: A Systemic Functional Perspective". TESOL Quarterly, 33(4): 759-763.

Daryanto. 2012. Evaluasi Pendidikan. Jakarta: Rineka Cipta. diakses melalui https://books.google.co.id

Halliday, M.A.K. dan Ruqaiya Hasan. 1992. Bahasa, Konteks, dan Teks. Yogyakarta: Gadjam Mada Press.

Harahap. 2018. Pemahaman Guru Bahasa Indonesia SMP dan SMA dalam Mengembangkan Butir-Butir Pembelajaran Kebahasaan Dengan Pendekatan Komunikatif Berbasis Teks. PENA. Vol. 8 No. 1. 2018. E-ISSN: 2615-7705. P-ISSN: 2089-3973.

Harsiati, Titik.dkk. 2013. Modul Pembelajaran Berbasis Teks. Penelitian BOPTN.

Irwan, Muhammad, 2011. Desertasi : Pemahaman dan Kesadaran Muzakki dalam Pelaksanaan Zakat Infak dan Shadaqah (ZIS) untuk Mencapai
Kesejahteraan Umat Islam di Kota Bima Provinsi NTB. Universitas Airlangga Surabaya. diakses pada 16 agustus 2019 melalui

http://ejournal.mandalanursa.org/index.p hp/JUPE/article/view/518/501

Kemendikbud. 2017. Buku Guru Bahasa Indonesia: Untuk SMA, SMK, MAK. Jakarta. Pusat Kurikulum dan Perbukuan, Balitbang, Kemendikbud.

Knapp, Peter dan Watkins, Megan. 2005. Genre, Text, Grammar: Technologies for Theaching and Assessing Writing. Sidney, Australia: University of New South Wales Press Ltd.

Kosasih. 2016. Jenis-jenis Teks: Analisis Fungsi, Struktur, dan Kaidah serta Langkah Penulisannya: Dalam Mata Pelajaran Bahasa Indonesia SMA/SMK/MA. Bandung: Yrama Widya Nuh, Muhammad. 2013. Menyemai Creator Peradaban: Renungan Tentang Pendidikan, Agama, Dan Budaya. Jakarta: Zaman

Mahnun. 2019. Kemampuan Memproduksi Teks Laporan Hasil Observasi Siswa X SMA 9 Mataram. Skripsi S1, FKIP Universitas Mataram.

Mahsun, Dkk. 2017. "Laporan Penelitian Kemampuan Memproduksi Teks Genre Cerita Melalui Metode Saintifik Siswa Kelas XI SMA di Kota Mataram”. FKIP. Program Pascasarjana Pendidikan Bahasa Indonesia: LPMP Universitas Mataram.

Mahsun. 2014. Teks Dalam Pembelajaran Bahasa Indonesia. Depok : PT Rajawali. Pers

Mahsun. 2017. Metode penelitian bahasa. Depok : PT Rajawali Pers.

Mahsun. 2017. Pembelajaran Bahasa Indonesia Berbasis Teks. Depok : PT Rajawali. Pers

Mahsun. 2018. Pembelajaran Bahasa Indonesia Berbasis Teks. Depok : PT Rajawali. Pers

Miftahul K., Sakura R. 2014. Sintaksis: Memahami Satuan Kalimat Perspektif Fungsi. Jakarta: PT Bumi Aksara.

Rahman, dkk. (2018) Implementasi Pembelajaran Bahasa Indonesia 
Terakreditasi Peringkat 5 (No. SK: 85/M/KPT/2020)

Berbasis Teks Di SMP Negeri

Kabupaten Padang Pariaman. Jurnal

Pendidikan Bahasa Dan Sastra Indonesia. Vol. 7 No. 2 September 2018; Seri A 9-16.

Sugiyono, 2011. Metodologi Penelitian Pendidikan, Pendekatan Kuantitatif, Kualitatif, dan $R$ and $D$, Alfabeta, Bandung

Suriati, dkk. 2018. Kemampuan Menggunakan Majas Perbandingan Dalam Memproduksi Teks Eksemplum Siswa Kelas IX. Jurnal Lingua, vol 15, no. 2, September 2018. p-ISSN: 1979-19411, e-ISSN: 2442-238x.

Suryani, dkk. 2014. Pembelajaran Bahasa Indonesia berbasis Teks di Kelas X SMA Negeri 1 Singaraja. E-jurnal Pendidikan Bahasa dan Sastra Indonesia, Undiksha. Vol. 1 No. 1. 2014. 